Premiere Educandum: Jurnal Pendidikan Dasar dan Pembelajaran

Volume 11 (2) 227 - 242 December 2021

ISSN: 2088-5350 (Print) / ISSN: 2528-5173 (Online)

Doi: $10.25273 /$ pe.v11i2.9187

The article is published with Open Access at: http://e-journal.unipma.ac.id/index.php/PE

\title{
Content analysis of the nature of science on elementary thematic textbooks 2013 curriculum
}

Irfan Jaenudin, SDN Gadog 04 Bogor / Universitas Pendidikan Indonesia Pratiwi Nur Aisyiah $\bowtie$, SD Bianglala Bandung / Universitas Pendidikan Indonesia Rani Suryani, SDN 1 Cisande Sukabumi / Universitas Pendidikan Indonesia Ari Widodo, Universitas Pendidikan Indonesia

$\bowtie$ pratiwinuraisyiah@upi.edu

Abstract: The 2013 curriculum thematic learning book is used as the primary textbook in thematic learning in elementary schools. This study aims to describe the Nature of Science (NOS) content in the book. This study used a descriptive quantitative research design with the research objects are thematic learning textbooks for 2013 curriculum elementary school students from grades 1-6. Data were collected through observation techniques using a research instrument that contains the analysis of the aspects of the NOS. The data are analyzed through grouping, scoring, determining the validity and reliability, then describing and drawing conclusions. The results showed that the level of content of the NOS in the thematic learning books of the 2013 curriculum elementary school students was $12 \%$, so that it could be categorized as significantly less. These data illustrate that the aspects of the NOS in thematic books already exist but have not been fully presented explicitly, correctly, entirely, and consistently.

Keywords: the nature of science, content analysis, thematic books, curriculum 2013

Received 05 May 2020; Accepted 02 September 2021; Published 01 December 2021

Citation: Jaenudin, I., Aisyiah, P.N., Suryani, R., Widodod, A. (2021). Content analysis of the nature of science on elementary thematic textbooks 2013 curriculum. Premiere Educandum : Jurnal Pendidikan Dasar dan Pembelajaran, 11(2), 227 - 242. Doi.org/10.25273/ pe.v11i2.9187

\section{(cc) BY-NC-SA}

Published by Universitas PGRI Madiun. This work is licensed under the Creative Commons Attribution-NonCommercialShareAlike 4.0 International License. 


\section{INTRODUCTION}

The nature of science or Nature of Science (NOS) is a fundamental foundation in teaching science to schools. Science education aims to equip students to apply science skills to understand various kinds of natural phenomena and build students' awareness of scientific literacy through their understanding of the nature of science (Lederman, Lederman, \& Antink, 2013). However, the achievement of these goals is still a big challenge for the education process in Indonesia. The report on the results of the Program for International Student Assessment (PISA) survey by The Organization for Economic CoOperation and Development (OECD) revealed that since the last few years, Indonesia has still positioned itself as one of the countries with a low level of scientific ability.

This low scientific ability is caused by students' low understanding of the nature of science (Widodo, Jumanto, Adi, \& Imran, 2019). Several other studies on understanding the nature of science in elementary schools also reveal that the understanding of NOS for students in Indonesia is in sufficient category (Lestari \& Rahmawati, 2020), for teachers in sufficient category (Adi \& Widodo, 2018), and for prospective teachers in good category (Rahayu \& Widodo, 2019). This illustrates that the level of understanding of the nature of science, especially in students, has not achieved the desired understanding (Adi \& Widodo, 2018).

One of the factors that causes this student's low understanding of the nature of science is the lack of NOS content in the textbooks used by teachers in schools (Rusilowati, Nugroho, \& Susilowati, 2016). The textbooks used today are more dominant in presenting science content textually. Meanwhile, the way for students to gain knowledge of science as a whole does not yet fully exist. Based on its role, textbooks are a vital medium in conveying information from teachers to students (Maturradiyah \& Rusilowati, 2015). Considering the use of textbooks to be one of the important learning tools in improving students' scientific abilities, this study intends to analyze the existence of the content of the nature of science presented on the 2013 curriculum thematic books as the main books in learning in elementary schools.

\section{The Nature of Science}

The nature of science (NOS) can be defined as a term that describes standard operating procedures in scientific activities that help students understand how knowledge is acquired and scientifically accepted (McComas, 2017). The term NOS is more oriented towards the characteristics of scientific knowledge, which is essentially obtained through the process of scientific investigation (Lederman, Antink, \& Bartos, 2014). In essence, the nature of science is an epistemology of science that discusses how knowledge is obtained and can be proven true.

There are seven main aspects in the construction of the nature of science which consist of: (1) empirical base, (2) tentative, (3) theories and law, (4) socio cultural embeddedness, (5) creativity, (6) scientific method, and (7) subjective (Widodo et al., 2019). The empirical base can be interpreted as knowledge obtained based on empirical evidence or actual events that occur, can be felt through the five senses, and is based on observational and/or experimental evidence. Tentative means that the truth of scientific knowledge obtained is not absolute and final, so it can be changed or refined based on existing situations and conditions and is supported by new observational evidence. Theories and law are a product of scientific knowledge that explains the mechanism of a phenomenon in the form of a law that explains the relationship between observed phenomena. Socio-cultural embeddedness means that scientific knowledge cannot be separated from the prevailing social and cultural components and has been embedded in an environment where such knowledge is practiced, understood, and accepted by society. Although scientific knowledge is empirically based on observations of nature, it is also 
produced through the imagination and creativity of humans or scientists in a logical, systematic, and growing manner. Science method means that scientific knowledge is obtained through various methods or processes of scientific discovery that are not singular, universally applicable, and countable. Then, subjective scientific knowledge is based on an individual point of view motivated by experience, commitment, mindset, and idealism that affect a scientist working, investigating, observing, understanding, and interpreting data.

These aspects of the nature of science have a significant role to be taught in the learning process of Natural Sciences in elementary schools. A complete understanding of the nature of science for students helps equip them with scientific work skills. This skill can be applied as an essential ability in everyday life (Adi \& Widodo, 2018). Based on its benefits, there are several conclusions about the importance of the nature of science in science learning in schools, including: (1) Utilitarian: the nature of science is needed to be able to understand natural phenomena in everyday life; (2) Democratic: the nature of science is needed to train decision-making skills in solving a scientific social problem; (3) Cultural: the nature of science is needed to build awareness in appreciating and appreciating the values of science as part of contemporary culture; (4) Moral: the nature of science helps in understanding the prevailing norms and building commitment to practice in a community; (5) Science learning: the nature of science is needed as a medium that accommodates the delivery of science material (McComas, 2017).

\section{Thematic Learning Book}

Textbooks contain certain scientific studies compiled by experts based on learning objectives and are equipped with several teaching elements that can make it easier for readers to understand the contents to support the learning activities being carried out (Maturradiyah \& Rusilowati, 2015). At the elementary level, thematic textbooks are an essential part of the implementation of the 2013 curriculum nationally because it is used as the main handbook. This textbook integrates several subjects into specific themes. This book contains learning activities, information on learning materials, learning indicators, and basic competencies that students need to master with a scientific approach design and authentic assessment (Novianto, 2015).

The quality of the thematic learning books used influences the quality of the learning it supports. Good and quality textbooks are books with relevant content and support the achievement of curriculum implementation because textbooks and curriculum have a close relationship with each other(Jannah, Suyana, \& Novia, 2019).

In line with the role and function of thematic textbooks, as well as the implementation of the objectives of the 2013 curriculum, which emphasizes the mastery of attitudes, knowledge, and skills, the content of the 2013 curriculum thematic textbooks should not only focus on presenting knowledge or cognitive aspects but also process skills, and student attitudes. Especially the 2013 curriculum thematic book as a book that integrates several subjects into one theme, where science learning is included, so the book is deemed necessary to present the elements of the nature of science explicitly in it.

\section{METHOD}

\section{Research design}

This study uses a quantitative descriptive research design with a content analysis approach in elementary thematic learning books. This study aims to describe the level of existence of the nature of science in the thematic learning books for elementary school students in the 2013 curriculum. 


\section{Object of research}

The object of this research is a textbook for elementary school students. The population is all elementary thematic books from grades 1-6, with a sample of several thematic book pages containing Basic Science Competencies on each learning theme.

\section{Research Instruments}

The data collection instrument used in this study was a document observation sheet. This sheet was developed based on seven aspects of the nature of science developed from previous research on understanding Nature of Science (NOS) by elementary school students and teachers (Widodo et al., 2019). More clearly, the following are indicators of aspects of the nature of science used in this research:

TABLE 1. Indicators of aspects of the Nature of Science/NOS

\begin{tabular}{|c|c|c|}
\hline No. & Aspect & Indicator \\
\hline 1. & Empiric base & $\begin{array}{l}\text { a. Scientific knowledge is based on data/evidence obtained from } \\
\text { observation with the five senses } \\
\text { b. Scientific knowledge is based on data/evidence obtained from } \\
\text { experiments }\end{array}$ \\
\hline 2. & Tentative & $\begin{array}{l}\text { a. Scientific knowledge is not something that is absolutely correct } \\
\text { and without error, but lasts long enough to be revised } \\
\text { b. Scientific knowledge can be changed (enhanced) by new } \\
\text { observational evidence and by reinterpretation of existing } \\
\text { observations }\end{array}$ \\
\hline 3. & $\begin{array}{l}\text { Theories and } \\
\text { law }\end{array}$ & $\begin{array}{l}\text { a. Laws describe relationships, observations or perceptions, } \\
\text { phenomena in nature and are usually accompanied by } \\
\text { mathematical formulas } \\
\text { b. Theories are inferred explanations for natural phenomena and } \\
\text { the mechanisms of relationships between natural phenomena }\end{array}$ \\
\hline 4. & $\begin{array}{l}\text { Socio cultural } \\
\text { embeddedness }\end{array}$ & $\begin{array}{l}\text { a. Science is the result of human effort, therefore, the process of } \\
\text { acquiring scientific knowledge is influenced by the society and } \\
\text { culture in which it is practiced } \\
\text { b. Value systems and culture will influence what and how this } \\
\text { scientific knowledge is practiced, interpreted, and received }\end{array}$ \\
\hline 5. & Creativity & $\begin{array}{l}\text { a. Scientific knowledge is created from human imagination, } \\
\text { creativity, and logical reasoning } \\
\text { b. Creativity and imagination make scientific knowledge will } \\
\text { continue to grow } \\
\text { c. The creation of scientific knowledge is based on creative } \\
\text { planning, observation, and inference }\end{array}$ \\
\hline 6. & $\begin{array}{l}\text { Scientific } \\
\text { method }\end{array}$ & $\begin{array}{l}\text { a. There is no definite and universally applicable scientific method } \\
\text { b. To conduct research, scientists are free to use any method as long } \\
\text { as it is accountable }\end{array}$ \\
\hline 7. & Subjective & $\begin{array}{l}\text { a. Personal subjectivity is inevitable in science } \\
\text { b. Personal values, beliefs, agendas, and previous experiences will } \\
\text { influence what and how a scientist does his job }\end{array}$ \\
\hline
\end{tabular}

\section{Research procedure}

The research was started by conducting a literature review from various primary sources, which was then developed as an instrument of observation sheet that contained aspects of the nature of science being analyzed and its indicators. The next step is the data collection stage. This stage is carried out by carefully reading and recording the data per paragraph on each page and analyzing and matching it with the indicators on the observation sheet. Then, the occurrence of aspects of the nature of science in each paragraph is counted and 
documented. This reading and recording are carried out by researchers with the knowledge, thoroughness, and criticality of researchers in finding and collecting the data needed under the research problem.

\section{Data analysis}

Data analysis in this study was carried out through several stages. The first stage is a grouping and scoring the data. The results of recording findings in thematic books are grouped based on each aspect of the nature of the empirical science. Then, each class's aspects of the nature of science are converted into scores and added up. Researchers then convert the results of the summation of the scores into percentages.

The second is the determination of the validity and reliability of the data. The validity of the data was carried out through semantic validity, namely data validity techniques that were carried out by looking at the suitability of the data and interpreted according to the context or concept that had been chosen(Novianto, 2015). The reliability of the analysis data is measured by calculating the level of agreement between observers in analyzing aspects of the nature of science in thematic books. The higher the level of Coefficient of Agreement, the reliability of a data analysis result will be better. The observers' coefficient of agreement was categorized into the following categories: $<0.40$ : very bad; 0.40 - 0.75: good; and > 0.75: very good (Maturradiyah \& Rusilowati, 2015). The results of the agreement coefficient of the observers in this study were classified in the very good category with the following results:

TABLE 2. Recapitulation of coefficient of agreement

\begin{tabular}{cccc}
\hline \multirow{2}{*}{ No. } & Book & \multicolumn{2}{c}{ Coefficient of Deal } \\
& & $(\mathrm{KK})$ & Categori \\
\hline 1. & Grade 1 & 0,85 & Very good \\
2. & Grade 2 & 0,85 & Very good \\
3. & Grade 3 & 0,85 & Very good \\
4. & Grade 4 & 1 & Very good \\
5. & Grade 5 & 1 & Very good \\
6. & Grade 6 & 1 & Very good \\
\hline
\end{tabular}

The last stage is a description and drawing conclusions. The percentage level of the content of the aspects of the nature of science in each class is described to understand the meaning of each existing data, and then conclusions are drawn from the research results. The description of the level of content of the nature of science in this thematic book is done by comparing the percentage of observations on each observed aspect based on the existing categories. This description process is also linked and strengthened with the results of the research literature review from various studies that previous researchers have carried out.

More clearly, the following are the categories of content levels of the nature of science used in this research:

TABLE 3. Category of science content level

\begin{tabular}{cc}
\hline Percentage Rate (\%) & Categori \\
\hline $81-100$ & Very good \\
$61-80$ & Well \\
$41-60$ & Enough \\
$21-40$ & Not enough \\
$\leq 20 \mathrm{~s}$ & Very less \\
\hline
\end{tabular}




\section{RESULT}

Based on the results of data analysis and processing that has been carried out in this study, it is known that the aspects of the nature of science in students' thematic books already exist, but the percentage level of the content of the nature of science is still in the very poor category. The following is results table of the emergence aspects analysis of the nature of science on the thematic books of elementary school students in the 2013 curriculum:

TABLE 4. Results of the analysis of the nature of science

\begin{tabular}{lccccccc}
\hline \multicolumn{1}{c}{ Aspect } & \multicolumn{9}{c}{ Grade } & \multicolumn{3}{c}{ Aspect } \\
& 1 & 2 & 3 & 4 & 5 & 6 & $\begin{array}{c}\text { Average } \\
(\%)\end{array}$ \\
\hline Empiric Base & $(\%)$ & $(\%)$ & $(\%)$ & $(\%)$ & $(\%)$ & $(\%)$ & $(17)$ \\
Tentative & 0 & 17 & 17 & 36 & 36 & 48 & 25,7 \\
Theories and Law & 0 & 0 & 0 & 0 & 0 & 0 & 0 \\
Socio Cultural & 0 & 8 & 11 & 36 & 36 & 52 & 23,8 \\
Creativity & 0 & 0 & 0 & 0 & 0 & 0 & 0 \\
Science Method & 0 & 0 & 0 & 0 & 0 & 0 & 0 \\
Subjective & 0 & 8 & 17 & 36 & 36 & 52 & 24,8 \\
$\quad$ Book Average (\%) & 0 & 0 & 0 & 0 & 21 & 37 & 9,7 \\
\hline
\end{tabular}

TABLE 5. Analysis of the nature of science in class 1 thematic books

\begin{tabular}{lccccccccc}
\hline \multicolumn{1}{c}{ Aspect } & \multicolumn{1}{c}{ Theme } & & & \multirow{2}{*}{ Aspect } \\
& 1 & 2 & 3 & 4 & 5 & 6 & 7 & 8 & Average \\
\hline Empiric Base & $(\%)$ & $(\%)$ & $(\%)$ & $(\%)$ & $(\%)$ & $(\%)$ & $(\%)$ & $(\%)$ & \\
Tentative & 0 & 0 & 0 & - & - & 0 & 0 & 0 & 0 \\
Theories and Law & 0 & 0 & 0 & - & - & 0 & 0 & 0 & 0 \\
Socio Cultural & 0 & 0 & 0 & - & - & 0 & 0 & 0 & 0 \\
Creativity & 0 & 0 & 0 & - & - & 0 & 0 & 0 & 0 \\
Science Method & 0 & 0 & 0 & - & - & 0 & 0 & 0 & 0 \\
Subjective & 0 & 0 & 0 & - & - & 0 & 0 & 0 & 0 \\
$\quad$ & 0 & 0 & 0 & - & - & 0 & 0 & 0 & 0 \\
\multicolumn{1}{r}{ Theme Average } & 0 & 0 & 0 & - & - & 0 & 0 & 0 & 0 \\
\hline
\end{tabular}

The percentages in table 4. show the level of content of the nature of science for each aspect analyzed in thematic books from grades 1-6. It can be seen that overall the thematic books for the 2013 curriculum in each class have not fully presented the content of aspects of the nature of science aspect explicitly, entirely, and consistently

The average percentage of all thematic books from grades 1-6 for the empirical base, theories and law, scientific method, and subjective aspects is $25.7 \%, 23.8 \%, 24.8 \%$, and 9.7, respectively\%. As for the other three aspects, such as the tentative, socio-cultural, and creativity aspects, respectively, were $0 \%$ or meaning that none of them appeared.

The average percentage of the nature of science content in each thematic book from grades $2-6$, respectively, is $4.7 \%, 6.4 \%, 15.4 \%, 18.4 \%$, and $27 \%$. Meanwhile, thematic books in grade 1 have a science content level of $0 \%$, or nothing appears.

That way, the average percentage of the content of aspects of science in the thematic books for elementary school students in the 2013 curriculum from grades $1-6$ is $12 \%$ or can be categorized in the category that is still very lacking. Only $12 \%$ of the total number of pages analyzed, from grades 1-6, shows the content of the nature of science and is presented explicitly. Meanwhile, $88 \%$ of all thematic books have not explicitly fully 
contained aspects of science's nature. This explicit submission means that the statement's writing is conveyed clearly, explicitly, and logically with the aspect of the nature of the observed science. The following is a detailed analysis of the nature of science in the thematic books in each class:

The table above shows that the thematic books for grade 1 that do not contain science competencies are in themes 4 and 5 , while they contain science competencies for other themes. The analysis of the nature of science in grade 1 thematic books shows that in all the themes that contain science competencies, no editorial shows the aspects of the nature of science presented explicitly. The percentage rate for each theme indicates this is $0 \%$.

TABLE 6. Analysis of the nature of science in class 2 thematic books

\begin{tabular}{lccccccccc}
\hline \multicolumn{1}{c}{ Aspect } & \multicolumn{1}{c}{ Theme } & & \multicolumn{2}{c}{ Aspect } \\
& 1 & 2 & 3 & 4 & 5 & 6 & 7 & 8 & Average \\
\hline Empiric Base & $(\%)$ & $(\%)$ & $(\%)$ & $(\%)$ & $(\%)$ & $(\%)$ & $(\%)$ & $(\%)$ & \\
Tentative & 0 & 50 & - & - & - & 0 & - & - & 17 \\
Theories and Law & 0 & 0 & - & - & - & 0 & - & - & 0 \\
Socio Cultural & 0 & 25 & - & - & - & 0 & - & - & 8 \\
Creativity & 0 & 0 & - & - & - & 0 & - & - & 0 \\
Science Method & 0 & 0 & - & - & - & 0 & - & - & 0 \\
Subjective & 0 & 25 & - & - & - & 0 & - & - & 8 \\
$\quad$ & 0 & 0 & - & - & - & 0 & - & - & 0 \\
$\quad$ Theme Average & 0 & 14 & - & - & - & 0 & - & - & 4,7 \\
\hline
\end{tabular}

TABLE 7. Results of analysis of the nature of science in class 3 thematic books

\begin{tabular}{lccccccccc}
\hline \multicolumn{1}{c}{ Aspek } & \multicolumn{1}{c}{ Tema } & \multicolumn{1}{c}{ Aspect } \\
& $(\%)$ & 2 & 3 & 4 & 5 & 6 & 7 & 8 & Average \\
\hline Empiric Base & 0 & 0 & $(\%)$ & $(\%)$ & $(\%)$ & $(\%)$ & $(\%)$ & $(\%)$ & \\
Tentative & 0 & 0 & 0 & - & 0 & 0 & - & - & 17 \\
Theories and Law & 0 & 0 & 55 & - & 0 & 0 & - & - & 0 \\
Socio Cultural & 0 & 0 & 0 & - & 0 & 0 & - & - & 11 \\
Creativity & 0 & 0 & 0 & - & 0 & 0 & - & - & 0 \\
Sciencetific Method & 0 & 0 & 85 & - & 0 & 0 & - & - & 17 \\
Subjective & 0 & 0 & 0 & - & 0 & 0 & - & - & 0 \\
$\quad$ Theme Average & 0 & 0 & 32 & - & 0 & 0 & - & - & 6,4 \\
\hline
\end{tabular}

Grade 2 thematic books containing science competencies consist of themes 1, 2, and 6. While themes $3,4,5,7$, and 8 do not contain science competencies. Based on the results of the analysis of the nature of science in the table above, the average percentage of editorial appearances describing the nature of science is $4.7 \%$ or categorized as very poor.

Among the three themes that contain science competencies, only theme 2 in grade 2 thematic books explicitly presents the nature of science, although it is still very low. In theme book 1, the percentage of findings from the nature of science being analyzed is $0 \%$ or not found. In theme book 2 the percentage for the empirical base aspect is $50 \%$ (there are 14 statements out of 28 that illustrate that scientific knowledge is based on empirical evidence). Aspects of theories and law are 25\% (7 statements out of 28 statements illustrate that scientific knowledge can be in the form of law or theory). The science method aspect is $25 \%$ ( 7 of the 28 statements describe that scientific knowledge is obtained using any scientific method that can be justified). 
As for theme book 6, the percentage of findings from the nature of science being analyzed is $0 \%$ or not found. Thus, average percentages for each aspect of the empirical base, theories and law, and scientific method in grade 2 thematic books are $17 \%, 8 \%$, and $8 \%$, respectively.

Grade 3 thematic books that contain science competencies consist of themes 1, 2, 3, 5 , and 6. While themes 4, 7, and 8 do not contain science competencies. Based on the information in the table above, we can see that the nature of science only appears explicitly in theme 3 books, while it is not found in other themes. There are three aspects observed in theme book 3: empirical base, theories and law, and the scientific method. In theme book 3, the percentage of the empirical base aspect is $85 \%$ (there are 23 statements out of 27 statements that illustrate that scientific knowledge is based on empirical evidence). The percentage for the theory and law aspect is 55\% (15 statements out of 27 that illustrate that scientific knowledge can be in the form of law or theory). The percentage for the science method aspect is $85 \%$ (there are 23 statements out of 27 that illustrate that scientific knowledge is obtained using any scientific method that can be justified).

The average percentage content of science in grade 3 thematic books is $6.4 \%$ or significantly less, with the average aspects for the empirical base, theories and law, and science method respectively $17 \%, 11 \%$, and $17 \%$.

In contrast to the thematic books for lower grades (1-3), thematic books for upper grades (4-5) already contain science competencies in each theme. As for the results of the analysis of the level of the nature of science in each top-grade thematic book, we can see in the following table:

TABLE 8. Results of analysis of the nature of science in grade 4 thematic books

\begin{tabular}{lcccccccccc}
\hline \multicolumn{1}{c}{ Aspect } & \multicolumn{1}{c}{ Theme } & \multicolumn{1}{c}{ Aspect } \\
& 1 & 2 & 3 & 4 & 5 & 6 & 7 & 8 & 9 & $\begin{array}{c}\text { Average } \\
\text { Ampiric Base }\end{array}$ \\
Tentative & 78 & 70 & 30 & 20 & 24 & 30 & 24 & 24 & 24 & 36 \\
Theories and Law & 0 & 0 & 0 & 0 & 0 & 0 & 0 & 0 & 0 & 0 \\
Socio Cultural & 0 & 80 & 0 & 0 & 45 & 36 & 0 & 40 & 34 & 36 \\
Creativity & 0 & 0 & 0 & 0 & 0 & 0 & 0 & 0 & 0 & 0 \\
Science Method & 80 & 80 & 20 & 20 & 40 & 0 & 36 & 30 & 15 & 36 \\
Subjective & 0 & 0 & 0 & 0 & 0 & 0 & 0 & 0 & 0 & 0 \\
$\quad$ Theme Average & 35 & 33 & 7 & 6 & 16 & 10 & 9 & 13 & 10 & 15,4 \\
\hline
\end{tabular}

The results of the analysis of the nature of science in grade 4 thematic books are still in the very poor category. The overall average percentage is $15.4 \%$, with the percentage level for the empirical base, theories, law, and science method aspects is $36 \%$. The content of the essence of science is mostly found in themes 1 and 2, with an average percentage of $35 \%$ and $33 \%$. The themes with the lowest percentage level of the essence of science are themes 4 and 3, which are $6 \%$ and $7 \%$.

At the highest level of content of the nature of science, for the theme book 1 the percentage of the empirical base aspect is $78 \%$ (there are 32 out of 41 existing statements describing that scientific knowledge is based on empirical evidence). The percentage for the theory and law aspect is $85 \%$ (35 of the 41 statements illustrate that scientific knowledge can be in the form of theory or law). The percentage for the science method aspect is $80 \%$ (33 out of 41 existing statements describe that scientific knowledge is obtained using the scientific method that can be justified). In theme 2 the percentage of the empirical base aspect is $70 \%$ (28 of the 40 existing statements describe that scientific knowledge is based on empirical evidence). The percentage for the theory and law aspect 
is $80 \%$ ( 32 of the 40 statements illustrate that scientific knowledge can be in the form of theory or law). The percentage for the science method aspect is $80 \%$ (32 of the 40 existing statements describing that scientific knowledge is obtained through the scientific method that can be justified).As for the lowest level of content of the nature of science, for the theme book 3 on the empirical base aspect, it is 30\% (there are 9 out of 30 existing statements describing that scientific knowledge is based on empirical evidence). The percentage for the science method aspect is $20 \%$ (there are 6 out of 30 existing statements describing that scientific knowledge is obtained through the scientific method that can be justified). In theme 4, the percentage for the empirical base aspect is $20 \%$ (there are 5 of the 25 statements that describe scientific knowledge based on empirical evidence). The percentage for the science method aspect is $20 \%$ (there are 5 of the 25 existing statements describing that scientific knowledge is obtained through the scientific method).

TABLE 9. Results of analysis of the nature of science in grade 5 thematic books

\begin{tabular}{lcccccccccc}
\hline \multicolumn{1}{c}{ Aspect } & \multicolumn{1}{c}{ Theme } & \multicolumn{1}{c}{ Aspect } \\
& 1 & 2 & 3 & 4 & 5 & 6 & 7 & 8 & 9 & $\begin{array}{c}\text { Average } \\
\text { Empiric Base }\end{array}$ \\
Tentative & 15 & 0 & 15 & 22 & 38 & 88 & 85 & 15 & 45 & 36 \\
Theories and Law & 0 & 0 & 0 & 0 & 0 & 0 & 0 & 0 & 0 & 0 \\
Socio Cultural & 10 & 0 & 20 & 20 & 45 & 80 & 82 & 35 & 30 & 36 \\
Creativity & 0 & 0 & 0 & 0 & 0 & 0 & 0 & 0 & 0 & 0 \\
Scientific Method & 0 & 0 & 0 & 0 & 0 & 0 & 0 & 0 & 0 & 0 \\
Subjective & 15 & 0 & 15 & 25 & 40 & 80 & 85 & 15 & 45 & 36 \\
$\quad$ Theme Average & 20 & 0 & 0 & 20 & 0 & 50 & 50 & 25 & 25 & 21 \\
\hline
\end{tabular}

Overall, the average percentage of science in grade 5 thematic books is $18.4 \%$ or very less, with the percentage level for the empirical base, theories and law, and science method aspects is $36 \%$ and for the subjective aspect is $21 \%$. The content of the nature of science is mostly found in themes 6 and 7 with an average percentage for each theme is $43 \%$. The theme with the lowest occurrence rate of the nature of science is theme 3 and theme 1 with a percentage rate of $7-9 \%$.

At the highest level of content of the nature of science, for the theme book 6 , the percentage of the empirical base aspect is $88 \%$ (there are 35 out of 40 existing statements describing that scientific knowledge is based on empirical evidence). The percentage for the theory and law aspect is $80 \%$ (32 of the 40 statements illustrate that scientific knowledge can be in the form of theory or law). The percentage for the science method aspect is $80 \%$ (32 of the 40 existing statements describing that scientific knowledge is obtained using the scientific method that can be justified). The percentage for the subjective aspect is $50 \%$ (there are 20 of the 40 statements that illustrate that the personal value of a scientist influences scientific knowledge in carrying out an investigative activity. In theme 7 , the percentage of the empirical base aspect is $85 \%$ (there are 34 out of 40 statements); the existing ones illustrate that scientific knowledge is based on empirical evidence. The percentage for the theories and law aspects is $82 \%$ (33 out of 40 existing statements describing that scientific knowledge can be in the form of theory or law). The percentage for the science method aspect is $85 \%$ (34 out of 40 existing statements describe that scientific knowledge is obtained using scientific methods that can be accounted for.) The percentage for the subjective aspect is $50 \%$ (there are 20 out of 40 existing statements describing that the personal value influences scientific knowledge in doing his job).

As for the lowest level of content of the nature of science, for theme 1 book on the empirical base aspect, it is $15 \%$ (there are 6 out of 40 existing statements describing that scientific knowledge is based on empirical evidence). The percentage for the theories and 
law aspects is $10 \%$ (4 out of 40 existing statements describing that scientific knowledge can be in the form of theory or law). The percentage for the science method aspect is $15 \%$ ( 6 out of 40 existing statements describing that scientific knowledge is obtained using the scientific method that can be justified). The percentage for the subjective aspect is $20 \%$ (there are 8 out of 40 existing statements describing that the personal value of a scientist influences scientific knowledge in doing his work). In theme 3 , the percentage of the empirical base aspect is $15 \%$ (there are 5 of the 34 existing statements describing that scientific knowledge is based on empirical evidence). The percentage for the theories and law aspects is $20 \%$ ( 7 out of 34 existing statements describing that scientific knowledge can be in the form of theory or law). The percentage for the science method aspect is $15 \%$ ( 5 out of 34 existing statements describe that scientific knowledge is obtained using the scientific method that can be justified).

TABLE 10. Analysis of the nature of science thematic books grade 6

\begin{tabular}{lcccccccccc}
\hline \multicolumn{1}{c}{ Aspect } & \multicolumn{1}{c}{ Theme } & \multicolumn{1}{c}{ Aspect } \\
& 1 & 2 & 3 & 4 & 5 & 6 & 7 & 8 & 9 & $\begin{array}{c}\text { Asverage } \\
\text { Empiric Base }\end{array}$ \\
Tentative & 40 & 40 & 66 & 66 & 100 & 20 & 0 & 100 & 0 & 48 \\
Theories and Law & 0 & 0 & 0 & 0 & 0 & 0 & 0 & 0 & 0 & 0 \\
Socio Cultural & 45 & 45 & 70 & 75 & 100 & 35 & 0 & 100 & 0 & 52 \\
Creativity & 0 & 0 & 0 & 0 & 0 & 0 & 0 & 0 & 0 & 0 \\
Science Method & 0 & 0 & 0 & 0 & 0 & 0 & 0 & 0 & 0 & 0 \\
Subjective & 45 & 45 & 70 & 70 & 100 & 40 & 0 & 100 & 0 & 52 \\
$\quad$ Theme Average & 40 & 0 & 60 & 72 & 80 & 0 & 0 & 80 & 0 & 37 \\
\hline
\end{tabular}

The level of content of the nature of science for all themes in grade 6 thematic books is $27 \%$, or in the less category, with the percentages for the empirical base, theories and law, scientific method, and subjective aspects respectively are $48 \%, 52 \%, 52 \%$, and $37 \%$. The nature of science in this book is mostly found in theme 5 and theme 8 with an average percentage of $54 \%$ in both themes. The themes that contain the least aspects of the nature of science are in theme 6 and theme 2, with percentage rates of occurrence of $14 \%$ and $19 \%$, respectively.

At the highest level of content of the nature of science, for the theme book 5 the percentage of the empirical base aspect is $100 \%$ (45 of the 45 statements illustrate that scientific knowledge is based on empirical evidence). The percentage for the theory and law aspect is $100 \%$ ( 45 of the 45 statements illustrate that scientific knowledge can be in the form of theory or law). The percentage for the science method aspect is $100 \%$ (45 of the 45 statements illustrate that scientific knowledge is obtained using the scientific method that can be justified). The percentage for the subjective aspect is $80 \%$ (there are 36 of the 45 statements that illustrate that the personal value of a scientist influences scientific knowledge in carrying out an investigation activity. In theme 8 , the empirical base aspect percentage is $100 \%$ (40 of 40 statements; the existing ones illustrate that scientific knowledge is based on empirical evidence. The percentage for the theories and law aspects is $100 \%$ ( 40 of the 40 existing statements illustrate that scientific knowledge can be in the form of theories or laws). The percentage for the science method aspect is $100 \%$ (40 of the 40 existing statements describe that scientific knowledge is obtained using scientific methods that can be accounted for.) The percentage for the subjective aspect is $80 \%$ (there are 32 out of 40 existing statements describing that the personal value of a scientist influences scientific knowledge in doing his job).

As for the lowest level of content of the nature of science, for the theme book 2 on the empirical base aspect, it is $40 \%$ (there are 16 of the 40 existing statements describing that scientific knowledge is based on empirical evidence). The percentage for the theories 
and law aspects is $45 \%$ (18 of the 40 statements illustrate that scientific knowledge can be in the form of theories or laws). The percentage for the science method aspect is $45 \%$ (18 of the 40 existing statements describe that scientific knowledge is obtained using the scientific method that can be justified). In theme 6 , the percentage of the empirical base aspect is $20 \%$ (there are 8 out of 34 existing statements describing that scientific knowledge is based on empirical evidence). The percentage for the theories and law aspects is 35\% (14 of the 34 existing statements illustrate that scientific knowledge can be in the form of theories or laws). The percentage for the science method aspect is $40 \%$ (16 of the 34 existing statements describe that scientific knowledge is obtained using the scientific method that can be justified).

\section{DISCUSSION}

In general, from the results of the analysis of this study, the thematic books for elementary school students in the 2013 curriculum from grades 1-6 have not presented the content of the nature of science explicitly. The average percentage of occurrences of aspects of the nature of science being analyzed is indicated, which are still in the very poor category. The lack of content on the nature of science presented in this thematic book will undoubtedly affect elementary school students' low understanding of science. It is in line with the results of previous studies, which showed that one of the factors that led to the low level of understanding of the nature of science (NOS) of students was the lack of presentation of the content of the nature of science in the textbooks used by each school (Rusilowati et al., 2016).

The aspects of the nature of science contained in the new thematic book raise four aspects of the seven aspects analyzed. This occurrence has an average percentage rate of occurrence that is still low or less. This finding is in line with the results of previous studies, which showed that of the many science knowledge books analyzed, not all aspects analyzed were contained in it, while some aspects showed that the level of content of the nature of science was still relatively low (Jannah et al., 2019).

The first aspect of the nature of science, namely the empirical base, is the aspect that is considered to have the most significant percentage of occurrences but is still not optimal. It is because thematic books more directly present the concept of science, while the facts or empirical evidence are less presented. The second aspect, tentative, has not yet appeared in the analyzed book. Books tend to discuss science concepts directly, but there are no explanatory sentences that build students' understanding of the openness of a theory that it will continuously evolve and can be retested based on facts or evidence of new findings. The third aspect, theory, and law have appeared in the analyzed book but is not yet optimal. It is due to the lack of presentation of facts or evidence from observations and experiments so that the relationships and explanations of the natural phenomena studied are less visible.

The fourth aspect, socio-cultural, has not appeared in the analyzed book. The explanation of the concept in the book has not combined the socio-cultural conditions that exist in an environment and their influence on finding the concept to the practice of applying the concept in the community. Fifth, namely, the aspect of creativity, has not been explicitly shown in the analyzed book. There are no written sentences in the book that encourage students to do a creative activity that makes students discover new knowledge or products. Books mostly write activities to carry out the discovery process and make existing products, so students have to practice again.

The sixth is the aspect of the scientific method. This aspect has been found in many books, but it is not optimal due to the lack of scientific methods such as direct and specific inquiry activities that students practice. Seventh, subjective aspects have been found in the book but are not yet optimal. Books do not involve students' diversity when carrying out the scientific method process in generating or discovering new knowledge for themselves. 
Thematic books focus more on presenting science products in the form of a collection of materials used by students to practice their ability to remember and understand an object of knowledge. It is under previous research, which states that science textbooks used by teachers in schools emphasize more on aspects of knowledge presented in the form of facts, concepts, principles, laws, hypotheses, theories, models, and stimulate students to be able to remember knowledge or information(Maturradiyah \& Rusilowati, 2015).

Thematic books have not been dominant in stimulating students to develop thinking skills and perform science process skills as expected. Thematic books still have similarities like science textbooks in general which only present a collection of knowledge for students to remember. It is undoubtedly one of the evidence of learning science that has not entirely taught the nature of science. As the results of previous studies stated that one of the problems in learning the nature of science is that the majority of books used in learning often ignore aspects of scientific inquiry, scientific thinking, and social aspects of science and focus too much on presenting scientific knowledge (Jiang \& McComas, 2014).

When compared, the percentage level of analysis of the nature of science in thematic books for each class shows the condition that is not much different. The percentage level of the content of the nature of science in thematic books for grades 1-5 is in the very poor category, while for grade 6 it is increasing and is in the poor category. This condition requires teachers to be creative in accompanying the use of thematic books with certain learning activities that can train students' abilities in the nature of science. Several previous research results explain that the nature of science needs to be taught through reflective and explicit learning (Widodo et al., 2019). In addition, prioritizing the achievement of NOS aspects can be an alternative that has been proven to train students' understanding of the nature of science (Lestari \& Widodo, 2021).

The analysis of thematic books on each learning theme from the lower and upper classes showed an uneven distribution. The findings of aspects of the nature of science for lower grade thematic books from 1-3 are centered in one theme and are not found in other themes. Moreover, for each theme in the first-grade thematic books, there is no visual aspect of the nature of science. It is because, based on Permendikbud no. 37 of 2018, science learning in the 2013 curriculum for grades 1-3 is not oriented towards scientific inquiry and is only limited to introductions presented in the form of scientific knowledge. Therefore, in the 2013 curriculum, there are no science competencies that are explicitly taught to students in grades 1-3, but these competencies are integrated into Indonesian language competencies as an introductory topic for students to learn language skills such as reading, writing, and speaking.

Unlike the thematic books used by upper-class students (4-6), science learning has been included in the curriculum content and stands alone as a thematically integrated subject. However, based on the analysis results, the even distribution across all themes has not been accompanied by a percentage level that is still ideal. The concept of the nature of science in some aspects found is still implicit or indirect, even though it needs to be taught explicitly to students, one of which is in the textbook through its editorial, which describes several aspects of the nature of science. It is, of course, so that students can understand the concept of science and the concept of the nature of science in particular (Adi \& Widodo, 2018). The nature of science taught explicitly can improve students' ability to effectively understand the nature of science (Imran \& Widodo, 2018).

This study describes that the 2013 curriculum thematic books already contain aspects of science but are still in the very poor category. The content of the nature of science, which is still very lacking in this thematic book, can undoubtedly impact the science learning process carried out in elementary schools. In addition, this can impact the level of understanding of students and teachers who are less developed. The lack of textbooks containing the nature of science will negatively impact teachers' understanding, classroom learning, and students' understanding of science (Lestari \& Rahmawati, 2020). 
he lack of content of the nature of science in thematic books can also impact students' scientific literacy skills. It is because the ability to understand the nature of science is the basis that can help students achieve scientific literacy skills. Students' nature of science is influential in mastering scientific literacy skills (Khishfe, 2017). That is why the results of the PISA survey, which measures the level of scientific and mathematical literacy of students in several countries in recent years, often show that the ability of students to understand science in Indonesia is still in low order. It is undoubtedly inseparable from one of its effects, namely the use of textbooks used.

These impacts certainly require other efforts to accompany the use of the 2013 curriculum thematic books as the main handbook in elementary learning. The critical effort that needs to be done is to encourage teachers to continually deepen their insights regarding studying the nature of science (Jumanto \& Widodo, 2018). However, the teacher's level of understanding of the nature of science and how to apply it in learning has implications for students' understanding of the nature of science (Hacieminoglu, 2014). It is also reinforced by the results of other studies, which state that the teacher's NOS conception has an important influence on students' NOS understanding. It has been consistently proven in research that teachers' conceptions of NOS have the same qualifications or are similar to the conceptions of NOS in students (Wahbeh \& Abd-ElKhalick, 2014).

Improving teachers' ability to understand the concept of the nature of science and how to integrate it into learning requires a program to increase the competence and professionalism of teachers related to NOS-based learning. It is in line with the results of previous studies, which stated that competency improvement programs like this significantly reflected the experience of teachers and increased their understanding of NOS (Adibelli Sahin \& Deniz, 2017) and (Cofré, Cuevas, \& Becerra, 2017). It is also corroborated by other studies that state that training activities like this need to be carried out to provide an understanding of NOS and how to pursue it (Mıhladız \& Doğan, 2014). Not only for teachers, but this program also needs to be built since someone becomes a prospective teacher so that their readiness in teaching the nature of science can be more mature (Adi \& Widodo, 2018). The results of previous research stated that teachers' experience in integrating the nature of science while studying in college was advantageous in the learning practices they carried out in the classroom (Hacieminoglu, 2014).

Teachers also need to have a strong will to bring the nature of science they have learned from the program into their learning. Given, in addition to the teacher's understanding factor that is still odd with the concept of the nature of science(Jumanto \& Widodo, 2018), The reluctance of teachers to integrate aspects of the nature of science into learning is also one of the factors that make students' level of understanding of science still not developed as expected (Lestari \& Rahmawati, 2020).

On the other hand, the appropriate learning approach in teaching science also needs to be considered. However, the NOS cannot be taught indirectly and naturally grows during learning, but it is necessary to use a contextual reflective learning approach explicitly taught to students (Chaiyabang \& Thathong, 2014). Lectures should not be the only method, and students also need to be explained about the historical background of the discovery of scientific knowledge by a scientist (Adi \& Widodo, 2018). It needs to be presented in writing in the textbooks used to realize that scientific knowledge has tentative and socio-cultural properties. As explained in previous research, the historical approach contained in textbooks can increase students' awareness of the nature of science, which is tentative and influenced by socio-cultural scientists(Hacieminoglu, 2014). Likewise, laboratory-based learning is a method that can support the development of students' insights about how science is carried out and discovered (McComas, 2015). Through laboratory activities, students can understand the workings of scientific knowledge concretely. It also builds a classroom environment that raises the role of students as questioners, observers, researchers, discoverers, and aware that science is related to everyday events. 


\section{CONCLUSION}

The results of this study indicate that the level of content of the nature of science in the thematic learning books for elementary school students in the 2013 curriculum is very poor. The thematic book is more dominant in presenting a collection of scientific knowledge than teaching aspects of the nature of science in investigation activities, scientific thinking, and social aspects of science. It is evidenced by the results of the analysis of thematic books, which show that the average percentage of the content of the essence of science is $12 \%$, with an average percentage level for each aspect of the nature of science in the empirical base, theories and law, scientific method, and subjective respectively. participation were $25.7 \%, 23.8 \%, 24.8 \%$, and $9.7 \%$. Meanwhile, other aspects of the nature of science, such as tentative, socio-cultural, and creativity, are $0 \%$ or nothing appears at all.

Based on the research results that have been carried out, this study only examines the level of existence of aspects of the nature of science (NOS) in thematic learning books for elementary school students, curriculum 2013 from grades 1-6. As for suggestions for further research opportunities, it would be better if an in-depth study was conducted on the development of science-based textbooks, science-based assessment questions, sciencebased student worksheets, or the development of learning models based on an explicit and reflective approach. Effective contextual practice to train students' scientific nature skills, especially at the elementary school level.

\section{REFERENCES}

1. Adi, Y. K., \& Widodo, A. (2018). Pemahaman Hakikat Sains pada Guru dan Siswa Sekolah Dasar. Edukasi Journal, 10(1), 55-72. https://doi.org/10.31603/edukasi.v10i1.1831

2. Adibelli Sahin, E., \& Deniz, H. (2017). Elementary Teachers' Perceptions about The Effective Features of Explicit-Reflective Nature of Science Instruction. International Journal of Science Education, 39. https://doi.org/10.1080/09500693.2017.1308035

3. Chaiyabang, M. K., \& Thathong, K. (2014). Enhancing Thai Teacher's Understanding and Instruction of the Nature of Science. Procedia - Social and Behavioral Sciences, 116, 563-569. https://doi.org/10.1016/j.sbspro.2014.01.258

4. Cofré, H., Cuevas, E., \& Becerra, B. (2017). The Relationship Between Biology Teachers' Understanding of The Nature of Science and The Understanding And Acceptance of The Theory of Evolution. International Journal of Science Education, 39(16), 2243-2260. https://doi.org/10.1080/09500693.2017.1373410

5. Hacieminoglu, E. (2014). In-service Teachers' Perceptions Regarding their Practices Related to Integrating Nature of Science: Case Study. Procedia - Social and Behavioral Sciences, 116, 1268-1273. https://doi.org/10.1016/j.sbspro.2014.01.381

6. Imran, M. E., \& Widodo, A. (2018). Profil Pemahaman Nature of Science (NOS) di Sekolah Dasar. JKPD (Jurnal Kajian Pendidikan Dasar), 3(2), 540-557.

7. Jannah, N., Suyana, I., \& Novia, H. (2019). Analisis Hakikat Sains (Nature of Science) dalam Buku Teks Fisika SMA Kelas X di Kota Bandung. Ppprociding Smeinar Nasional Fisika 5.0, 1(1), 160-166.

8. Jiang, F., \& McComas, W. F. (2014). Analysis of Nature of Science Included in Recent Popular Writing Using Text Mining Techniques. Science \& Education, 23(9), 17851809. https://doi.org/10.1007/s11191-014-9703-0 
9. Jumanto, J., \& Widodo, A. (2018). Pemahaman Hakikat Sains oleh Siswa dan Guru SD di Kota Surakarta. Jurnal Komunikasi Pendidikan, 2(1), 20-31. https://doi.org/10.32585/jkp.v2i1.61

10. Khishfe, R. (2017). Consistency of Nature of Science Views Across Scientific and SocioScientific Contexts. International Journal of Science Education, 39(4), 403-432. https://doi.org/10.1080/09500693.2017.1287976

11. Lederman, N. G., Antink, A., \& Bartos, S. (2014). Nature of Science, Scientific Inquiry, and Socio-Scientific Issues Arising from Genetics: A Pathway to Developing a Scientifically Literate Citizenry. Science \& Education, 23(2), 285-302.

12. Lederman, N. G., Lederman, J. S., \& Antink, A. (2013). Nature of Science and Scientific Inquiry as Contexts for the Learning of Science and Achievement of Scientific Literacy. International Journal of Education in Mathematics, Science and Technology, 1(3), 138147.

13. Lestari, H., \& Rahmawati, I. (2020). Pemahaman NOS Peserta Didik Sekolah Dasar. Indonesian Journal of Science, 1(1), 18-25.

14. Lestari, H., \& Widodo, A. (2021). Peranan Model Pembelajaran Nature of Sains untuk Meningkatkan Pemahaman Sains Siswa Sekolah Dasar. Jurnal Cakrawala Pendas, 7(1), $1-9$.

15. Maturradiyah, N., \& Rusilowati, A. (2015). Analisis Buku Ajar Fisika SMA Kelas XII di Kabupaten Pati Berdasarkan Muatan Literasi Sains. Unnes Physics Education Journal, $4(1), 16-20$.

16. McComas, W. F. (2015). The Nature of Science \& the Next Generation of Biology Education. The American Biology Teacher, 77(7), 485-491. https://doi.org/10.1525/abt.2015.77.7.2

17. McComas, W. F. (2017). Understanding How Science Works: The. School Science Review, 98(365), 71-76.

18. Mıhladız, G., \& Doğan, A. (2014). Science Teachers' Views about NOS and the Place of NOS in Science Teaching. Procedia - Social and Behavioral Sciences, 116, 3476-3483. https://doi.org/10.1016/j.sbspro.2014.01.787

19. Novianto, A. (2015). Analisis Buku Teks Muatan Tematik Integratif, Scientific Approach, dan Authentic Assessment Sekolah Dasar. Jurnal Kependidikan, 45(1), 1-15.

20. Rahayu, A. H., \& Widodo, A. (2019). Understanding of Nature of Science Pre-Service Students and Elementary School Teachers in the Digital Age. Formatif: Jurnal Ilmiah Pendidikan MIPA, 9(2), 161-172. https://doi.org/10.30998/formatif.v9i2.3251

21. Rusilowati, A., Nugroho, S. E., \& Susilowati, S. M. (2016). Development of Science Textbook Based on Scientific Literacy for Secondary School. Jurnal Pendidikan Fisika Indonesia, 12(2), 98-105. https://doi.org/10.15294/jpfi.v12i2.4252

22. Wahbeh, N., \& Abd-El-Khalick, F. (2014). Revisiting the Translation of Nature of Science Understandings into Instructional Practice: Teachers' nature of science pedagogical content knowledge. International Journal of Science Education, 36(3), 425-466. https://doi.org/10.1080/09500693.2013.786852

23. Widodo, A., Jumanto, J., Adi, Y. K., \& Imran, M. E. (2019). Pemahaman Hakikat Sains (NOS) oleh Siswa dan Guru Sekolah Dasar. Jurnal Inovasi Pendidikan IPA, 5(2), $237-$ 247. https://doi.org/10.21831/jipi.v5i2.27294 


\section{PROFILE}

Irfan Jaenudin is a student of the Master of Basic Education Program, Postgraduate School, University of Indonesia Education. He is also a teacher who teaches at SDN Gadog $04 \mathrm{Kec}$. Megamendung, Kab. Bogor.

Pratiwi Nur Aisyiah is a student of the Master of Basic Education Program, Graduate School, University of Indonesia Education. He is also a teacher who teaches at Bianglala Elementary School, Bandung.

Rani Suryani is a student of the Master of Basic Education Program, Graduate School, University of Indonesia Education. He is also a teacher who teaches at SDN 1 Cisande, Kab. Sukabumi.

Ari Widodo is a lecturer in the Masters Program in Basic Education, Graduate School, University of Indonesia Education. He is also one of the Professors of the Indonesian University of Education in the field of Biology Education. In addition, he is active in research projects in the fields of biology education and basic education. 